\title{
Changes in nuclear factor kappa B components expression in the ovine spleen during early pregnancy
}

\author{
S. Hao, H. Fang, S. Fang, T. Zhang, L. Zhang and L. Yang* \\ Hebei University of Engineering, School of Life Sciences and Food Engineering, No. 19 Taiji Road, Handan 056038, China
}

KEY WORDS: nuclear factor kappa B component, pregnancy, sheep, spleen
Received: 30 September 2021

Revised: 25 January 2022

Accepted: 7 February 2022
* Corresponding author:

e-mail: yangling@hebeu.edu.cn

S. Hao and $\mathrm{H}$. Fang contributed equally to this work.

\begin{abstract}
Normal pregnancy is characterised by a systemic immunological tolerance against foetal antigens, and the spleen contributes to the adaptive immune tolerance during pregnancy. Nuclear factor kappa B (NF-KB) signallings participate in splenic immune regulation, but it is unclear whether there are changes in NF-KB components expression in the ovine spleen during early pregnancy. The objective of this study was to explore the effects of early pregnancy on the expression of NF-KB components in the maternal spleen in sheep. The spleens were sampled on day 16 of the oestrous cycle, and on days 13,16 and 25 of gestation. The expression of NF-KB components, including NF-KB1 (p50), NF-KB2 (p52), RelA (p65), RelB and $C$-Rel, were detected by quantitative real-time PCR, Western blot analysis and immunohistochemical analysis. The results showed that NF-KB1 and RelB mRNA and proteins decreased at days 13 and 16 of pregnancy, but increased at day 25 of pregnancy in comparison with that on day 16 of the oestrous cycle. Nevertheless, NF-KB2 and RelA mRNA and proteins peaked at days 13 and 16 of pregnancy. In addition, early pregnancy inhibited C-Rel expression at days 16 to 25 of pregnancy in the maternal spleen. In conclusion, the variable expression of individual NF-KB components was found in the ovine spleen during early pregnancy, which may be related with pregnancy recognition, and essential for the embryo implantation and pregnancy maintenance.
\end{abstract}

\section{Introduction}

There is an immunological tolerance against foetal antigens, which is induced by hormonal changes during pregnancy (Fuhler, 2020). Progesterone (P4) from corpus luteum (CL), pregnancy recognition signal (interferon tau, IFNT) from the conceptus and prostaglandins secreted by the endometria affect uterine functions, and contribute to conceptus elongation, implantation and establishment of pregnancy in ruminants (Spencer et al., 2016). Conceptus signal (IFNT) and high concentrations of P4 contribute to immunological forbearance through regulating innate immune system in the uterus, peripheral immune cells and other tissues during early pregnancy in ruminants (Ott, 2020). Interferon tau, with its paracrine and endocrine actions, adjusts the maternal innate immune system and avoids conceptus rejection, and other immune regulators, such as the pattern recognition receptors, work in parallel with IFNT during early pregnancy in ruminants (Rocha et al., 2021). Pattern recognition receptors contribute to the activation of nuclear factor kappa B (NF- $\kappa \mathrm{B})$ to result in the downstream activation of innate immune responses (Heilmann et al., 2017).

Nuclear factor kappa B family consists of

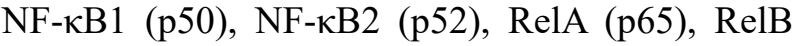
and $c-R e l$ that are involved in the regulation of development of the immune system, inflammation, and innate and adaptive immune responses in 
mammals (Patel et al., 2017). Prolactin reduces lipopolysaccharide-induced inflammatory cytokines via suppressing NF- $\kappa \mathrm{B}$ signalling in the cultured explants from human placentas, and has beneficial effects on trophoblast growth, placental angiogenesis and immunomodulation (Olmos-Ortiz et al., 2019). Lipopolysaccharide increases the expression of phosphatase and tensin homolog deleted on chromosome 10 via NF- $\mathrm{NB}$ pathway in trophoblasts, and reduces the ability of trophoblasts to invasion, which contributes to preeclampsia in a rat model (Xue et al., 2020). Tubulin polymerization-promoting protein 3 (TPPP3) contributes to the decidualization, and TPPP3 inhibition attenuates NF- $\kappa \mathrm{B}$ transcriptional promoter activity in human endometrial stromal cells, and has adverse effects on decidualization and embryo implantation (Shukla et al., 2019). Autophagy suppression enhances the invasiveness of the trophoblastic cell lines and $\mathrm{NF}-\kappa \mathrm{B}$ activity, but $\mathrm{NF}-\kappa \mathrm{B}$ inhibitor attenuates the trophoblast invasion (Oh et al., 2020). In addition, normal morula embryos and tumour necrosis factor $\alpha$ (TNF- $\alpha)$-treated morula embryos have differential effects on the expression of genes and proteins in uterine tissues and spleen through NF- $\kappa \mathrm{B}$ pathway during preimplantation pregnancy in mice (Buska-Mach et al., 2021). It is unclear whether the expression of NF- $\mathrm{BB}$ components in the spleen is changed during early pregnancy in ewes.

As the centre of the blood defense system, the spleen works together with the liver and bone marrow to activate the defense response through innate and adaptive immunity in humans (Kashimura, 2020). Oestrogen contributes to haematopoietic stem-cell self-renewal and erythropoiesis in the spleen during pregnancy in mice (Nakada et al., 2014). Pregnancy induces changes in the erythroid lineage and the immune system, and there is increase in the expression of erythropoietin receptor and a decrease in the expression of death receptor Fas in the spleen during pregnancy (Norton et al., 2009). It has been reported that there is up-regulation of interferon stimulated genes (ISGs), P4 receptor, P4-induced blocking factor, TNF- $\beta$, interleukin (IL)-2, IL-5, IL-6, IL-10, cyclooxygenase 2 , aldo-keto reductase family 1 , member B1, melatonin receptor 1 (MT1), gonadotropin releasing hormone and its receptor, and down-regulation of MT2 in the ovine maternal spleen during early pregnancy (Yang et al., 2018; Li et al., 2019; Wang et al., 2019; Bai et al., 2020; Cao et al., 2021). So, it was hypothesised that there are changes in $\mathrm{NF}-\kappa \mathrm{B}$ components expression in the ovine spleen during early pregnancy. The goal of this study was to compare the expression of $\mathrm{NF}-\kappa \mathrm{B} 1, \mathrm{NF}-\kappa \mathrm{B} 2$,
RelA, RelB and c-Rel in the maternal spleen during early pregnancy stages in sheep.

\section{Material and methods}

\section{Animals and experimental design}

The study was performed in the Department of Animal Science of the Hebei University of Engineering, Handan (China) on 24 Small-tail Han ewes. Animal procedures were approved by the Ethics Committee of the Hebei University of Engineering. After detection of oestrus (day 0 ) with a nepididymectomized ram, the females were randomly divided into four groups ( $\mathrm{n}=6$ for each group). The ewes from the group of day 16 of the oestrous cycle were not exposed to a fertile ram. The other 18 animals were randomly divided into three groups (days 13, 16 and 25 of pregnancy), and exposed to fertile rams. The effects of early pregnancy on the expression of prostaglandin (PG) synthases in the ovine thymuses and thymic weight are mainly due to P4 and IFNT. The reasons that expression of $\mathrm{NF}-\kappa \mathrm{B}$ components in the ovine spleen is changed during early pregnancy are mainly due to P4 and IFNT. There are significantly higher concentrations of P4 on days 12-13 in plasma, and lower concentrations of P4 on days 15-16 during the ovine oestrous cycle (McNatty et al., 1973). IFNT (Protein X) and additional proteins are detected between days 14 and 21 in sheep (Godkin et al., 1982). Day 13 of the oestrous cycle is almost similar to day 13 of pregnancy according to above reasons, and at this time there are no high concentrations of P4 and IFNT on day 16 of the oestrous cycle. The spleens were collected from 24 ewes on days 13, 16 and 25 post-breeding, and from ewes on day 16 of the oestrous cycle at the time of slaughter. Pregnancy was verified by observing a conceptus in the uterus for the pregnant ewes. The splenic transverse pieces $\left(0.5 \mathrm{~cm}^{3}\right)$ were fixed in fresh $4 \%(\mathrm{w} / \mathrm{v})$ paraformaldehyde (Sigma-Aldrich Corp., St. Louis, MO, USA) in phosphate buffered saline (PBS) (pH 7.4), and the remaining portions were frozen in a liquid nitrogen for subsequent mRNA and protein analyses.

\section{RNA extraction and $q R T-P C R$ assay}

Total RNA extraction was performed using TRIzol reagent (Invitrogen, California, USA) in accordance with manufacturer's instruction. Concentrations and purity of the total RNA were determined using spectrophotometry (Thermo Fisher Scientific, Wilmington, DE, USA), and absorbance ratio values (260/230) ranged between 2.0 to 2.2. Genomic DNA removal and complementary DNA synthesis 
from the total RNA were performed using a FastQuant RT kit (Tiangen Biotech Co., Ltd., Beijing, China). A Bio-rad CFX96 real-time PCR system (Bio-Rad Laboratories, Inc., CA, USA) was used for quantitative real-time PCR (qRT-PCR) assay with a SuperReal PreMix Plus kit (Tiangen Biotech Co., Ltd., Beijing, China). The optimized primer pairs of $N F-\kappa B 1, N F-\kappa B 2$, RelA, RelB, C-Rel and GAPDH were designed and synthesized by Shanghai Sangon Biotech Co., Ltd. (Shanghai, China) (Table 1) based on the mRNA sequence of target genes on Genbank (https://www.ncbi.nlm.nih.gov/genbank/). body (sc-8414, 1:1000; Santa Cruz Biotechnology, Inc., CA, USA), a mouse anti-NF- $\kappa$ B2 monoclonal antibody (sc-7386, 1:1000; Santa Cruz Biotechnology, Inc., CA, USA), a mouse anti-RelA monoclonal antibody (sc-8008, 1:1000; Santa Cruz Biotechnology, Inc., CA, USA), a mouse anti-RelB monoclonal antibody (sc-166416, 1:1000; Santa Cruz Biotechnology, Inc., CA, USA), and a mouse anti-c-Rel monoclonal antibody (sc-6955, 1:1000; Santa Cruz Biotechnology, Inc., CA, USA) at $4{ }^{\circ} \mathrm{C}$ overnight, respectively. The secondary antibody was antimouse IgG-HRP (BL001A; Biosharp, Hefei, China)

Table 1. Primers used for RT-qPCR

\begin{tabular}{|c|c|c|c|c|}
\hline Gene & Primer & Sequence & Size, bp & Accession No. \\
\hline \multirow[t]{2}{*}{$\overline{N F-K B 1}$} & Forward & CAAGCACAAGAAGGCAGCACAAC & 113 & XM_027970852.2 \\
\hline & Reverse & CAGCCATCAGCAGCAGCAGAC & & \\
\hline \multirow[t]{2}{*}{$N F-K B 2$} & Forward & GCCTGCTGAATGCCCTGTCTG & 146 & XM_042238744.1 \\
\hline & Reverse & СTCTGTTTCCTGTTCCACCGACTG & & \\
\hline \multirow[t]{2}{*}{ RelA } & Forward & TGGCGAGAGGAGCACAGACAC & 92 & XM_027959295.2 \\
\hline & Reverse & TGACCAGGGAGATGCGGACTG & & \\
\hline \multirow[t]{2}{*}{ RelB } & Forward & СGCTGACСTCTCСTCGСTCTC & 93 & XM_015100238.3 \\
\hline & Reverse & AAGCCGAAGCCATTCTCCTTGATG & & \\
\hline \multirow[t]{2}{*}{ C-Rel } & Forward & TCCTCCTCTGCGTCCATCTCAAG & 104 & XM_004005929.4 \\
\hline & Reverse & GTGGGGTGGGCGATTGATGAC & & \\
\hline \multirow[t]{2}{*}{ GAPDH } & Forward & GGGTCATCATCTCTGCACCT & 176 & NM_001190390.1 \\
\hline & Reverse & GGTCATAAGTCCCTCCACGA & & \\
\hline
\end{tabular}

The PCR reaction consisted of $95{ }^{\circ} \mathrm{C}$ for $10 \mathrm{~s}$, $60-62{ }^{\circ} \mathrm{C}\left(60{ }^{\circ} \mathrm{C}\right.$ for $N F-\kappa B 1$ and $N F-\kappa B 2,61{ }^{\circ} \mathrm{C}$ for C-Rel, $62^{\circ} \mathrm{C}$ for $\operatorname{Rel} A$ and $\operatorname{RelB}$ ) for $20 \mathrm{~s}$, and $72{ }^{\circ} \mathrm{C}$ for $25 \mathrm{~s}$, and the number of PCR cycle was 40 . Glyceraldehyde 3-phosphate dehydrogenase (GAPDH) was used as the reference gene, and the condition of $G A P D H$ PCR reaction was the same as the target genes, respectively. The $2^{-\Delta \Delta \mathrm{Ct}}$ analysis method (Livak and Schmittgen, 2001) was used to determine the relative expression values for qRT-PCR assay. The relative levels of the target genes were normalized using the mean cycle threshold (CT) values from the group of day 16 of the oestrous cycle.

\section{Western blot analysis}

Splenic samples were lysed in a RIPA buffer (BL504A, Biosharp, Hefei, China) at $4{ }^{\circ} \mathrm{C}$, and protein concentration was determined using a bicinchoninic acid protein assay kit (Tiangen Biotech Co., Ltd., Beijing, China) The extracts were boiled in loading buffer for $5 \mathrm{~min}$, and equal amounts of proteins were analysed by a SDS-polyacrylamide gel electrophoresis. Proteins were transferred to polyvinylidene fluoride membranes (Millipore Corp., Billerica, MA) that were blotted with 5\% nonfat milk at $4{ }^{\circ} \mathrm{C}$ overnight. The membranes were incubated with a mouse anti-NF- $\mathrm{B} 1$ monoclonal anti- at a concentration of $0.05 \mu \mathrm{g} / \mathrm{ml}$, and blots were visualized by enhanced chemiluminescence (Tiangen Biotech Co., Ltd., Beijing, China). Quantity One V452 (Bio-Rad Laboratories, Hercules, CA, USA) was used to digitally quantified the band intensities that were normalized using GAPDH with an antiGAPDH antibody (sc-20357, 1:1000; Santa Cruz Biotechnology, Inc., CA, USA).

\section{Immunohistochemical analysis}

Immunohistochemistry for RelA protein in the maternal spleen was performed as described previously (Wang et al., 2019). The 5- $\mu \mathrm{m}$ thick sections from paraffin-embedded splenic tissue were incubated at room temperature with the primary antibody specific to RelA (sc-8008, 1:200; Santa Cruz Biotechnology, Inc., CA, USA) in a humidified chamber at $4{ }^{\circ} \mathrm{C}$ overnight. Specific binding sites were visualized with a DAB kit (Tiangen Biotech Co., Ltd., Beijing, China), and then counterstained with haematoxylin (Sigma-Aldrich Corp., St. Louis, MO, USA). Negative controls were performed using antiserum-specific isotype diluted at concentrations equivalent to the primary antibody. The sections were observed with a light microscope (Nikon Eclipse E800, Japan), and photographed with a digital camera DP12. The images were examined 
independently by 4 observers in a blinded fashion, and the staining intensities for RelA were analyzed by assigning an immunoreactive intensity of a scale of 0 to 3 , as described previously (Kandil et al., 2007).

\section{Statistical analysis}

The experimental design was completely randomized, and relative abundance levels of mRNA and protein expression were analyzed by leastsquares ANOVA using a MIXED procedure of SAS software (Version 9.2; SAS Institute Inc., Cary, NC, USA). Data obtained from different spleens of ewes were analyzed for the main effects of day and status (cyclic or pregnant), and their interaction between day and status. All data were presented as the mean \pm standard error of the mean (SEM). Values of $P<0.05$ were deemed significant.

\section{Results}

\section{Relative expression levels of $N F-\kappa B 1$, $N F-\kappa B 2, \operatorname{Rel} A, \operatorname{RelB}$ and $C$-Rel mRNA in the spleen}

As shown in the Figure 1, the relative expression levels of $N F-\kappa B 1$ and RelB mRNA were downregulated at days 13 and 16 of pregnancy, but
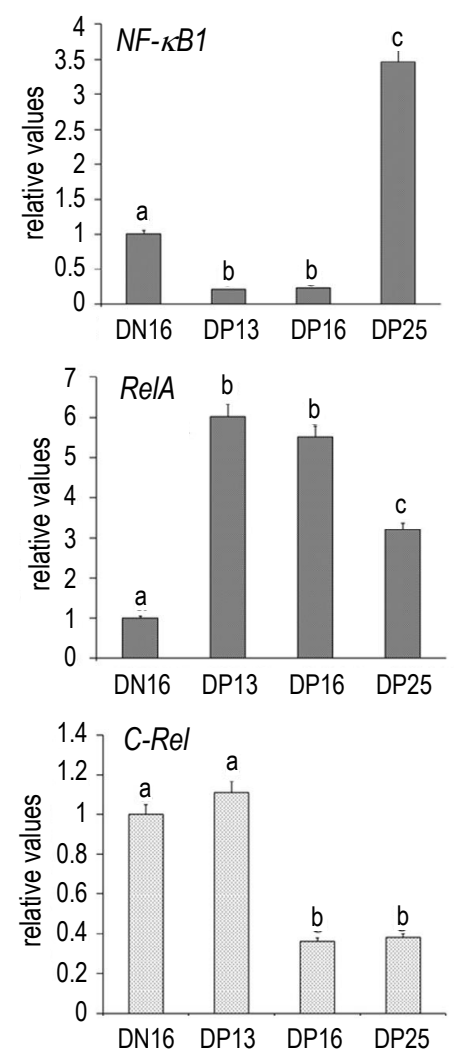

up-regulated at day 25 of pregnancy in comparison with that on day 16 of the oestrous cycle $(P<0.05)$. However, the relative expression levels of $N F-\kappa B 2$ and RelA were higher at days 13 and 16 of pregnancy than that at day 25 of pregnancy and on day 16 of the oestrous cycle $(P<0.05)$. In addition, early pregnancy induced down-regulation of $C$-Rel mRNA at days 16 to 25 of pregnancy in comparison with that on day 13 of pregnancy and day 16 of the oestrous cycle, but there was no significant difference between day 13 of pregnancy and day 16 of the oestrous cycle in the maternal spleen $(P>0.05$; Figure 1$)$.

\section{Expression of NF-кB1, NF-кB2, RelA, RelB and $c-$ Rel proteins in the spleen}

The expression levels of NF-kB1 and RelB proteins were higher on day 25 of pregnancy than on day 16 of the oestrous cycle $(P<0.05)$, and $\mathrm{NF}-\kappa \mathrm{B} 1$ and RelB proteins were undetected on days 13 and 16 of pregnancy (Figure 2). However, the expression levels NF- $\kappa \mathrm{B} 2$ and RelA proteins were up-regulated on day 13 and 16 of pregnancy, but there was no expression of RelA protein on day 16 of the oestrous cycle. In addition, the c-Rel protein level was significantly decreased at days 16 and 25 of pregnancy in comparison with that on
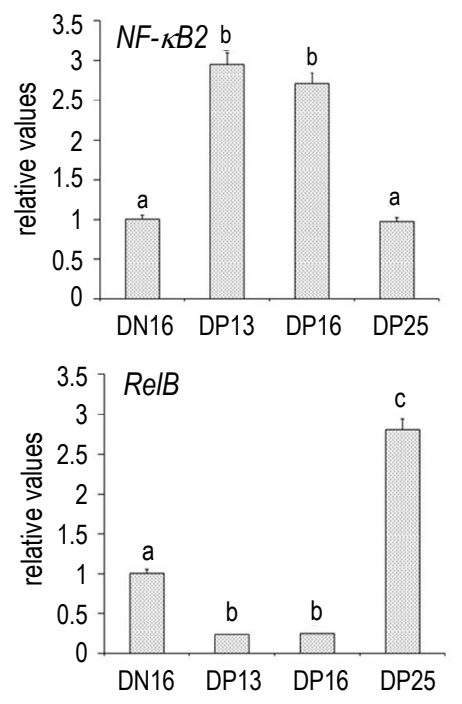

Figure 1. Relative expression values of NF-KB1,NF-KB2, RelA, RelB and C-Rel mRNA in the spleens of non-pregnant and pregnant ewes ( $n=6$ for each group) measured by quantitative real-time PCR

DN16 - day 16 of non-pregnancy, DP13 - day 13 of pregnancy, DP16 - day 16 of pregnancy, DP25 - day 25 of pregnancy; abc - bars with different superscripts are significantly different at $P<0.05$ 


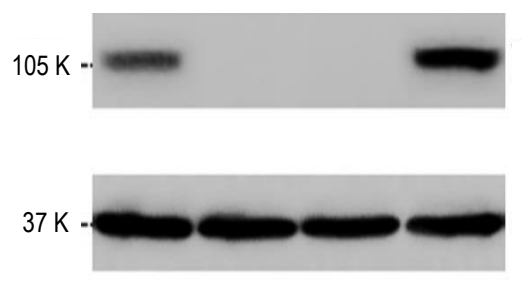

$\mathrm{NF}-\mathrm{\kappa B} 1$
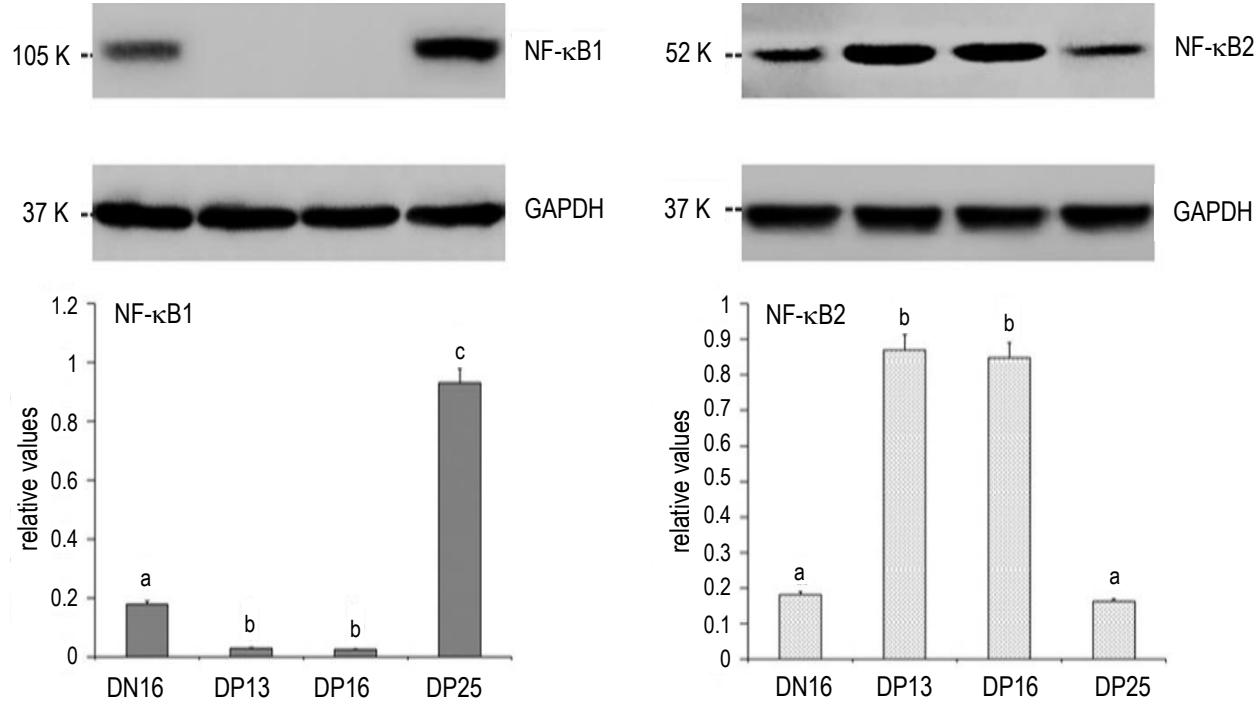

GAPDH

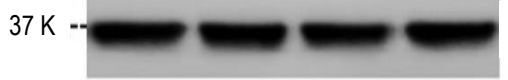

GAPDH
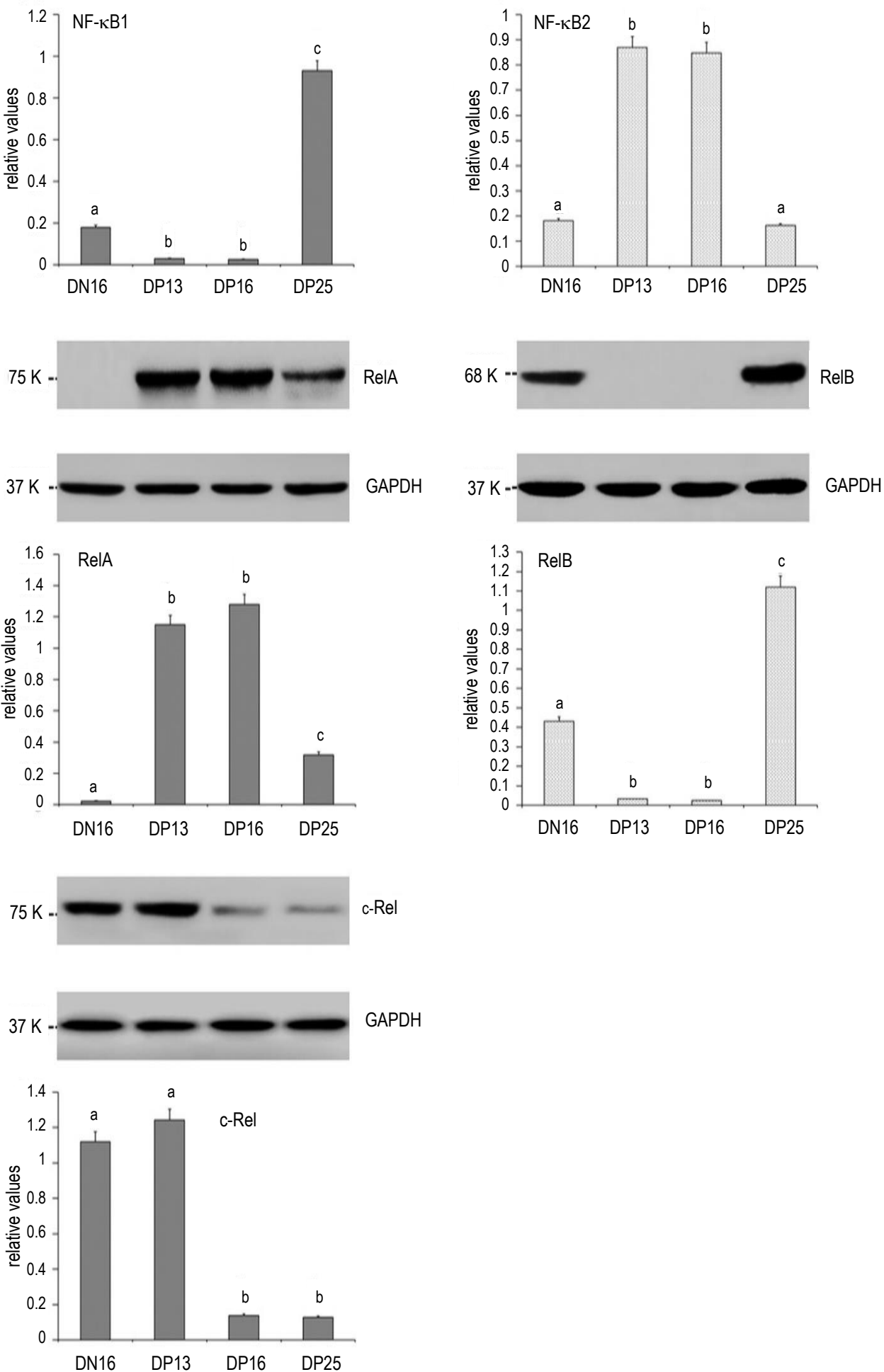

Figure 2. Expression of NF-kB1, NF-kB2, RelA, RelB and c-Rel proteins in the spleens of non-pregnant and pregnant ewes ( $\mathrm{n}=6$ for each group) analyzed with Western blot

DN16 - day 16 of non-pregnancy, DP13 - day 13 of pregnancy, DP16 - day 16 of pregnancy, DP25 - day 25 of pregnancy; $\mathrm{abc}-$ bars of the same colour with different superscripts are significantly different at $P<0.05$ 
day 13 of pregnancy and day 16 of the oestrous cycle $(P>0.05$; Figure 2$)$, and there was no significant difference between that at day 13 of pregnancy and on day 16 of the oestrous cycle, as well as between that at day 16 of pregnancy and at day 25 of pregnancy in the maternal spleen $(P>0.05$; Figure 2$)$.

\section{Immunohistochemistry for RelA protein in the spleen}

The RelA protein was mainly limited to the capsule, trabeculae and splenic cords (Figure 3). The staining intensities for RelA protein were $0,0,2+$, $2+$, and $1+$ for the negative control, the spleens from day 16 of the oestrous cycle, and spleens from days 13,16 , and 25 of pregnancy, respectively (Figure 3 ). The staining intensity was as follows: $0=$ negative; $1+=$ weak; $2+=$ strong.
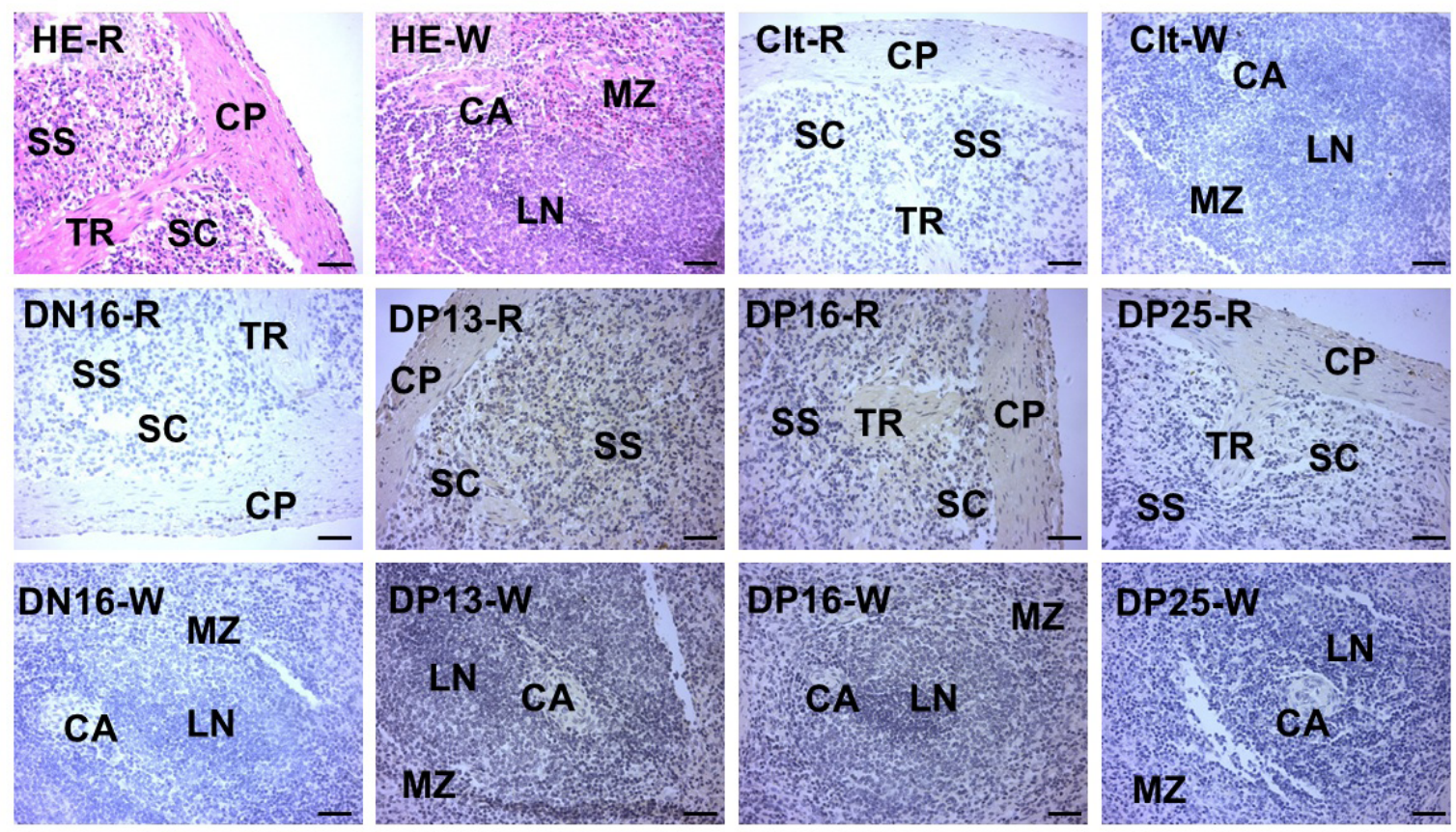

Figure 3. Representative immunohistochemical localization of RelA protein in the spleens of non-pregnant and pregnant ewes $(n=6$ for each group). The spleen is divided into red pulp (R) and white pulp (W), and surrounded by a thickened capsule (CP). Capsule (CP) with several trabeculae (TR) projects into the substance of the spleen.

$\mathrm{HE}$ - stained by hematoxylin and eosin, Ctl - negative control, SS - splenic sinuse, SC - splenic cords, MZ - marginal zone, LN - lymphoid nodule, CA - central arteriole, DN16 - day 16 of non-pregnancy, DP13 - day 13 of pregnancy, DP16 - day 16 of pregnancy, DP25 - day 25 of pregnancy; bar $-50 \mu \mathrm{m}$

\section{Discussion}

In this study, NF- $\mathrm{KB} 1$ decreased in the maternal spleen at days 13 and 16 of pregnancy, but increased at day 25 of pregnancy. NF- $\kappa$ B1 plays a key role in controlling lymphocyte and macrophage functions in immune and inflammatory responses, and NF- $\kappa$ B1 knockout displays multifocal defects in and the up-regulation of NF- $\mathrm{BB} 1$ at day 25 of pregnancy may be related to the embryo implantation.

Our data showed that RelB declined in the maternal spleen at days 13 and 16 of pregnancy, but was up-regulated at day 25 of pregnancy. RelB is essential for secondary lymphoid tissue organization and immune tolerance to inflammation, and RelB-deficient leads to premature mortality in mice 
(Baud and Collares, 2016). The pregnancy recognition signal IFNT (type I interferon) participates in the implantation and establishment of pregnancy in ruminants (Spencer et al., 2016), and also induces expression of ISGs in the ovine maternal spleen during early pregnancy (Yang et al., 2018; Wang et al., 2019). RelB is a negative regulator of the type I interferon signalling pathway in dendritic cells (Saha et al., 2020), and up-regulation of ISGs in the ovine maternal spleen may be related to the down-regulation of RelB in the spleen. RelB plays a key role in silencing or inhibiting the expression of the pro-inflammatory cytokines, and in a strong constitutive activation of RelB in decidual endothelial cells is beneficial for both avoiding pregnancy failure and immune tolerance to microorganisms during pregnancy (Masat et al., 2015). Therefore, it is suggested that the low level of RelB in the maternal spleen at days 13 and 16 of pregnancy may be related to the pregnancy recognition, and the upregulation of RelB at day 25 of pregnancy may be important for the embryo implantation and avoidance of pregnancy failure.

Our data indicated that early pregnancy induced expression of $N F-\kappa B 2$ at days 13 and 16 of pregnancy. NF- $\kappa \mathrm{B} 2$ is an inhibitor of $\kappa \mathrm{B}$ protein, and heterozygous NFKB2 mutations lead to a syndrome of immunodeficiency and autoimmunity in humans (Wirasinha et al., 2021). There was a marked decrease in the B cell compartment in the spleen in NF- $\kappa \mathrm{B} 2$-deficient mice, suggesting that $\mathrm{NF}-\kappa \mathrm{B} 2$ is essential for the maintenance of the peripheral $\mathrm{B}$ cell population, humoral responses, and normal spleen architecture (Caamaño et al., 1998). There were increases in NF- $\kappa \mathrm{B} 2$ protein in the $\mathrm{CL}$ on days 12,14 , and 16 of pregnancy, which is necessary for the survival of CL, secretion of P4 and the establishment of pregnancy in sheep (Lee et al., 2016). Therefore, the up-regulation of NF-kB2 in the maternal spleen at days 13 and 16 of pregnancy may be related to the establishment of pregnancy.

Our results revealed that early pregnancy enhanced the expression of RelA in the spleen, and RelA peaked at days 13 and 16 of pregnancy. In addition, RelA protein was mainly limited to the capsule, trabeculae and splenic cords. There is an absence of RelA in the NF-kB complex in peripheral blood mononuclear cells and liver of pregnant fulminant hepatic failure patients, suggesting that RelA suppression leads to deregulated immunity, as well as the death of the patient (Prusty et al., 2007). RelA protein increases in CL on days 12,14 , and 16 of pregnancy, which is related to CL survival,
P4 secretion and the establishment of pregnancy in sheep (Lee et al., 2016). In vivo oestrogen treatment suppresses the expression of RelA protein in mouse splenocytes, which contributes to the regulation of the immune system (Dai et al., 2007). It is has been reported that there is significantly lower plasma concentration of oestradiol-17 $\beta$ at days 10 and 20 of gestation in sheep (Hamon and Heap, 1990). Therefore, the up-regulation of RelA in the capsule, trabeculae and splenic cords of the maternal spleen during early pregnancy may be related to a lower concentration of plasma oestradiol-17 $\beta$, and so it could be beneficial for the establishment of pregnancy.

In this study, there was a decrease in the c-Rel expression at days 16 and 25 of pregnancy in the maternal spleen. NF- $\kappa \mathrm{B}$ subunit c-Rel is predominantly expressed in $\mathrm{B}$ cells that mediate humoral immune response and participate in the regulation of cellular immune response (Basavarajappa and Ramakrishnan, 2020), and is also involved in the maintenance of $\mathrm{B}$ cell mature in the spleen (Yamazaki and Kurosaki, 2003). The c-Rel level down-regulates the myometrium of pregnant women in comparison with nonpregnant controls, which is beneficial for pregnancy maintenance (Chapman et al., 2004). The expression of c-Rel protein in villi of the normal placenta is weak, which is related to the invasion and migration of choriocarcinoma cells (Sekiya et al., 2017). Thus, the decline of c-Rel at days 16 and 25 of pregnancy may be related to B cell mature in the spleen, and it contributes to the pregnancy maintenance.

\section{Conclusions}

A variable expression of individual $\mathrm{NF}-\kappa \mathrm{B}$ components in the maternal spleen during early pregnancy may be related to pregnancy recognition, embryo implantation, and pregnancy maintenance in sheep.

\section{Acknowledgments}

The current study was supported by the grants from Natural Science Foundation of Hebei Province, China (C2021402019), and Hebei Science and Technology Bureau, China (21326601D).

\section{Conflicts of interest}

The authors declare that there is no conflict of interest. 


\section{References}

Bai J., Zhang L., Zhao Z., Li N., Wang B., Yang L., 2020. Expression of melatonin receptors and CD4 in the ovine thymus, lymph node, spleen and liver during early pregnancy. Immunology 160, 52-63, https://doi.org/10.1111/imm.13180

Basavarajappa S.C., Ramakrishnan P., 2020. Regulation of B-cell function by NF-kappaB C-Rel in health and disease. Cell Mol. Life Sci. 77, 3325-3340, https://doi.org/10.1007/s00018-02003488-w

Baud V., Collares D., 2016. Post-translational modifications of RelB NF-kB subunit and associated functions. Cells 5, 22, https:// doi.org/10.3390/cells5020022

Beinke S., Ley S.C., 2004. Functions of NF-kappaB1 and NF-kappaB2 in immune cell biology. Biochem. J. 382, 393-409, https://doi. org/10.1042/BJ20040544

Bozkurt M., Şahin L., Ulaş M., 2015. Hysteroscopic polypectomy decreases NF-KB1 expression in the mid-secretory endometrium of women with endometrial polyp. Eur. J. Obstet. Gynecol. Reprod. Biol. 189, 96-100, https://doi.org/10.1016/j. ejogrb.2015.03.032

Buska-Mach K., Kedzierska A.E., Lepczynski A. et al., 2021. Differential signals from TNFa-treated and untreated embryos in uterine tissues and splenic CD4+ T lymphocytes during preimplantation pregnancy in mice. Front. Vet. Sci. 8, 641553, https://doi.org/10.3389/fvets.2021.641553

Caamaño J.H., Rizzo C.A., Durham S.K., Barton D.S., RaventósSuárez C., Snapper C.M., Bravo R., 1998. Nuclear factor (NF)-kappa B2 (p100/p52) is required for normal splenic microarchitecture and $\mathrm{B}$ cell-mediated immune responses. J. Exp. Med. 187, 185-196, https://doi.org/10.1084/ jem.187.2.185

Cao N., Cao L., Gao M., Wang H., Zhang L., Yang L., 2021. Changes in $\mathrm{mRNA}$ and protein levels of gonadotropin releasing hormone and receptor in ovine thymus, lymph node, spleen, and liver during early pregnancy. Domest. Anim. Endocrinol. 76, 106607, https://doi.org/10.1016/j.domaniend.2021.106607

Chapman N.R., Europe-Finner G.N., Robson S.C., 2004. Expression and deoxyribonucleic acid-binding activity of the nuclear factor kappaB family in the human myometrium during pregnancy and labor. J. Clin. Endocrinol. Metab. 89, 5683-5693, https://doi.org/10.1210/jc.2004-0873

Dai R., Phillips R.A., Ahmed S.A., 2007. Despite inhibition of nuclear localization of NF-kappa B p65, c-Rel, and RelB, 17-beta estradiol up-regulates NF-kappa B signaling in mouse splenocytes: the potential role of Bcl-3. J. Immunol. 179, 1776-1783, https://doi.org/10.4049/jimmunol.179.3.1776

Fuhler G.M., 2020. The immune system and microbiome in pregnancy. Best Pract. Res. Clin. Gastroenterol. 44-45, 101671, https:// doi.org/10.1016/j.bpg.2020.101671

Godkin J.D., Bazer F.W., Moffatt J., Sessions F., Roberts R.M., 1982. Purification and properties of a major, low molecular weight protein released by the trophoblast of sheep blastocysts at day 13-21. J. Reprod. Fertil. 65, 141-150, https://doi. org/10.1530/jrf.0.0650141

Hamon M.H., Heap R.B., 1990. Progesterone and oestrogen concentrations in plasma of Barbary sheep (aoudad, Ammotragus lervia) compared with those of domestic sheep and goats during pregnancy. J. Reprod. Fertil. 90, 207-211, https://doi. org/10.1530/jff.0.0900207

Heilmann R.M., Allenspach K., 2017. Pattern-recognition receptors: signaling pathways and dysregulation in canine chronic enteropathies-brief review. J. Vet. Diagn. Invest. 29, 781-787, https://doi.org/10.1177/1040638717728545
Kandil D., Leiman G., Allegretta M., Trotman W., Pantanowitz L., Goulart R., Evans M., 2007. Glypican-3 immunocytochemistry in liver fine-needle aspirates: a novel stain to assist in the differentiation of benign and malignant liver lesions. Cancer 111, 316-322, https://doi.org/10.1002/cncr.22954

Kashimura M., 2020. The human spleen as the center of the blood defense system. Int. J. Hematol. 112, 147-158, https://doi. org/10.1007/s12185-020-02912-y

Lee J., Banu S.K., McCracken J.A., Arosh J.A., 2016. Early pregnancy modulates survival and apoptosis pathways in the corpus luteum in sheep. Reproduction 151, 187-202, https://doi. org/10.1530/REP-15-0302

Li N., Zhao Z., Bai J., Liu B., Mi H., Zhang L., Li G., Yang L., 2019. Characterization of the Th cytokines profile in ovine spleen during early pregnancy. J. Appl. Anim. Res. 47, 386-393, https://doi.org/10.1080/09712119.2019.1634077

Livak K.J., Schmittgen T.D., 2001. Analysis of relative gene expression data using real-time quantitative PCR and the 2(-Delta Delta C(T)) Method. Methods 25, 402-408, https://doi.org/10.1006/ meth.2001.1262

Masat E., Gasparini C., Agostinis C., Bossi F., Radillo O., De Seta F., Tamassia N., Cassatella M.A., Bulla R., 2015. RelB activation in anti-inflammatory decidual endothelial cells: a master plan to avoid pregnancy failure? Sci. Rep. 5, 14847, https://doi. org/10.1038/srep14847

McNatty K.P., Revefeim K.J., Young A., 1973. Peripheral plasma progesterone concentrations in sheep during the oestrous cycle. J. Endocrinol. 58, 219-225, https://doi.org/10.1677/ joe. 0.0580219

Nakada D., Oguro H., Levi B.P., Ryan N., Kitano A., Saitoh Y., Takeichi M., Wendt G.R., Morrison S.J., 2014. Oestrogen increases haematopoietic stem-cell self-renewal in females and during pregnancy. Nature 505, 555-558, https://doi.org/10.1038/ nature12932

Nakamura H., Kimura T., Ogita K., Nakamura T., Takemura M., Shimoya K., Koyama S., Tsujie T., Koyama M., Murata Y., 2004. NF-kappaB activation at implantation window of the mouse uterus. Am. J. Reprod. Immunol. 51, 16-21, https:// doi.org/10.1046/j.8755-8920.2003.00116.x

Norton M.T., Fortner K.A., Bizargity P., Bonney E.A., 2009. Pregnancy alters the proliferation and apoptosis of mouse splenic erythroid lineage cells and leukocytes. Biol. Reprod. 81, 457-464, https://doi.org/10.1095/biolreprod.109.076976

Oh S.Y., Hwang J.R., Choi M., Kim Y.M., Kim J.S., Suh Y.L., Choi S.J., Roh C.R., 2020. Autophagy regulates trophoblast invasion by targeting NF-kB activity. Sci. Rep. 10, 14033, https://doi. org/10.1038/s41598-020-70959-2

Olmos-Ortiz A., Déciga-García M., Preciado-Martínez E. et al., 2019. Prolactin decreases LPS-induced inflammatory cytokines by inhibiting TLR-4/NFKB signaling in the human placenta. Mol. Hum. Reprod. 25, 660-667, https://doi.org/10.1093/molehr/ gaz038

Ott T.L., 2020. Immunological detection of pregnancy: Evidence for systemic immune modulation during early pregnancy in ruminants. Theriogenology $150,498-503$, https://doi. org/10.1016/j.theriogenology.2020.04.010

Patel H., Zaghloul N., Lin K., Liu S.F., Miller E.J., Ahmed M., 2017. Hypoxia-induced activation of specific members of the NF-kB family and its relevance to pulmonary vascular remodeling. Int. J. Biochem. Cell Biol. 92, 141-147, https://doi.org/10.1016/j. biocel.2017.09.022

Prusty B.K., Hedau S., Singh A., Kar P., Das B.C., 2007. Selective suppression of NF-kBp65 in hepatitis virus-infected pregnant women manifesting severe liver damage and high mortality. Mol. Med. 13, 518-526, https://doi.org/10.2119/2007-00055. Prusty 
Rocha C.C., da Silveira J.C., Forde N., Binelli M., Pugliesi G., 2021. Conceptus-modulated innate immune function during early pregnancy in ruminants: a review. Anim. Reprod. 18, e20200048, https://doi.org/10.1590/1984-3143AR2020-0048

Ross J.W., Ashworth M.D., Mathew D., Reagan P., Ritchey J.W., Hayashi K., Spencer T.E., Lucy M., Geisert R.D., 2010. Activation of the transcription factor, nuclear factor kappa-B, during the estrous cycle and early pregnancy in the pig. Reprod. Biol. Endocrinol. 8, 39, https://doi.org/10.1186/1477-7827-8-39

Saha I., Jaiswal H., Mishra R. et al., 2020. RelB suppresses type I Interferon signaling in dendritic cells. Cell Immunol. 349, 104043, https://doi.org/10.1016/j.cellimm.2020.104043

Sekiya Y., Yamamoto E., Niimi K., Nishino K., Nakamura K., Kotani T., Kajiyama H., Shibata K., Kikkawa F., 2017. c-Rel promotes invasion of choriocarcinoma cells via PI3K/AKT signaling Oncology 92, 299-310, https://doi.org/10.1159/000458529

Shukla V., Kaushal J.B., Sankhwar P., Manohar M., Dwivedi A., 2019. Inhibition of TPPP3 attenuates $\beta$-catenin/NF-KB/COX-2 signaling in endometrial stromal cells and impairs decidualization. J. Endocrinol. 240, 417-429, https://doi.org/10.1530/JOE-18-0459

Spencer T.E., Forde N., Lonergan P., 2016. The role of progesterone and conceptus-derived factors in uterine biology during early pregnancy in ruminants. J. Dairy Sci. 99, 5941-5950, https:// doi.org/10.3168/jds.2015-10070
Wang Y., Han X., Zhang L., Cao N., Cao L., Yang L., 2019. Early pregnancy induces expression of STAT1, OAS1 and CXCL10 in ovine spleen. Animals 9, 882, https://doi.org/10.3390/ ani9110882

Wirasinha R.C., Davies A.R., Srivastava M. et al., 2021. Nfkb2 variants reveal a p100-degradation threshold that defines autoimmune susceptibility. J. Exp. Med. 218, e20200476, https:// doi.org/10.1084/jem.20200476

Xue P., Fan W., Diao Z. et al., 2020. Up-regulation of PTEN via LPS/ AP-1/NF-KB pathway inhibits trophoblast invasion contributing to preeclampsia. Mol. Immunol. 118, 182-190, https://doi. org/10.1016/j.molimm.2019.12.018

Yamazaki T., Kurosaki T., 2003. Contribution of BCAP to maintenance of mature B cells through c-Rel. Nat. Immunol. 4, 780-786, https://doi.org/10.1038/ni949

Yang L., Guo R., Yao X., Yan J., Bai Y., Zhang L., 2018. Expression of progesterone receptor and progesterone-induced blocking factor in the spleen during early pregnancy in ewes. Livest. Sci. 209, 14-19, https://doi.org/10.1016/j.livsci.2018.01.004

Yang L., Liu Y., Lv W., Wang P., Wang B., Xue J., Zhang L., 2018. Expression of interferon-stimulated gene $15-\mathrm{kDa}$ protein, cyclooxygenase (COX) 1, COX-2, aldo-keto reductase family 1 , member B1, and prostaglandin $\mathrm{E}$ synthase in the spleen during early pregnancy in sheep. Anim. Sci. J. 89, 1540-1548, https://doi.org/10.1111/asj.13101 